\title{
Physicochemical characterization of Gozitan Honey
}

\author{
Everaldo AtTARD* AND Joseph Mizzi ${ }^{\mathrm{a}}$

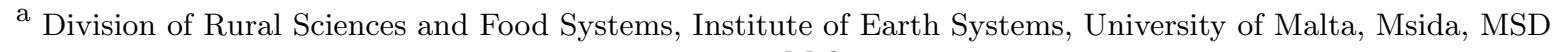 \\ 2080, Malta \\ ${ }^{*}$ Corresponding author \\ everaldo.attard@um.edu.mt \\ TEL: $+356-2340-2321$
}

Received: 23 November 2012; Published online: 18 October 2013

\begin{abstract}
Honey quality is clearly defined in the EU Directive 2001/110/EC, and by Codex Alimentarius (Codex Stan 12-1981) and the International Honey Commission (International Honey Commission, 2002). Our investigation aimed to characterize the physicochemical properties of honey produced on a small island, Gozo which is situated near Malta. Ten randomly collected honey samples were analysed for moisture content, $\mathrm{pH}$, free acidity, water insoluble content, hydroxymethylfurfural (HMF) content and total phenolic compounds. Moisture content, $\mathrm{pH}$, free acidity, water insoluble content, and HMF content were within the range specified in standards but the electrical conductivity was generally higher than $0.800 \mathrm{mS} \mathrm{cm}^{-1}$. This may be the result of the relatively high atmospheric and soil salinity on this small island. All the samples analysed were within the $40 \mathrm{mg} \mathrm{kg}^{-1} \mathrm{HMF}$ limit, which is an indicator of honey quality. The total phenolic compounds, which represent some of the constituents derived from the nectar and pollen obtained during foraging, ranged between 236.555 and $294.209 \mathrm{GAE} \mathrm{kg}^{-1}$ honey. Principal Component Analysis showed the properties of polyfloral honey samples obtained from the southern part of the island to be different from those obtained from the northern part.
\end{abstract}

Keywords: Gozitan honey; physicochemical characterization; polyphenols

\section{Introduction}

The isolated Maltese archipelago has a rich floral biodiversity and a distinct subspecies Apis mellifera ruttneri (Sheppard, Arias, Grech, \& Meixner, 1997), the Maltese honey bee. Honey production in Malta has a long history, dating back millennia, and still is one of the primary industrial sectors. Improvised sites, like natural or manmade recesses or caves in the rocks, and buildings can still be found scattered throughout the Maltese countryside, and they testify to how this industry evolved over time (Crane, 1983). There is a history of use of honey by the Maltese and Gozitan people, as a remedy, which is still a common practice nowadays. Honey was used to treat constipation, eye cysts, and wounds, and provide a source of food for weak children. However, the most common use was as a cough remedy, which was prepared by dissolving honey in warm water and then adding lemon juice or borage flowers. At times, honey was replaced by carob syrup. Honey was also mixed with orange blossom infusion to treat nervous tension and insomnia. For headaches, fever, and to clear the cornea, honey was mixed with apples, orange or lemon juice and greater celandine respectively. In preparation for labour, pregnant women were administered a mixture of honey, cloves, wine, cinnamon and other herbs (Lanfranco, 2001).

This study focuses on the quality of honey produced on the island of Gozo, the second largest island of the Maltese archipelago, situated at 
$36^{\circ} 03^{\prime} \mathrm{N} 14^{\circ} 15^{\prime} \mathrm{E}$. The island of Gozo, with approximately 31,053 inhabitants and a total surface area of $67 \mathrm{~km}^{2}$, is renowned for its conserved natural habitats and beautiful landscapes. This combination provides an ideal foraging ground for the honey bee. In this study the physicochemical characteristics of polyfloral honey, produced on this island, are reported.

\section{Materials and Methods}

Rough rice grains (cv. Urucuia), thin and long type, were harvested with a moisture Due to size limitations, the island was divided into distinct areas (Fig. 1). A sample representative of the area was randomly selected. Information on the honey samples was collected, and samples were subjected to physicochemical quality analysis.

\section{$2.1 \quad \mathrm{pH}$ and free acidity}

The methods adopted by the International Honey Commission (International Honey Commission, 2002) were used for the testing of $\mathrm{pH}$ and free acidity. Briefly, in a $250 \mathrm{~mL}$ beaker, 10

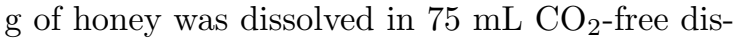
tilled water. Following $\mathrm{pH}$ reading, the diluted honey samples were titrated to $\mathrm{pH} 8.3$ with $0.1 \mathrm{M}$ $\mathrm{NaOH}$. The titration was completed within two minutes as lactone hydrolysis may lead to a continuous drift of the endpoint. The acidity was expressed as milliequivalents acid $\mathrm{kg}^{-1}$ honey = mL $0.1 \mathrm{M} \mathrm{NaOH}$ x 10.

\subsection{Moisture content}

The refractometric method was used to determine the moisture content. Homogenized honey samples were placed in a water bath at $50^{\circ} \mathrm{C}$ until all sugar crystals dissolved. Following cooling to $20^{\circ} \mathrm{C}, 2-3$ drops of homogenized honey were transferred to the prism of the refractometer (Atago 9520, Japan). The samples were read after two minutes. The moisture content was expressed as Moisture content $=100-$ Brix reading $\%$ g $100 \mathrm{~g}^{-1}$ honey. Extensive studies of local honey production by the authors indicate a reciprocal correlation between the moisture and Brix contents, adding up to $99.5 \pm 0.5 \%$.

\subsection{Water insoluble content}

$10 \mathrm{~g}$ honey samples were dissolved in $50 \mathrm{~mL}$ of distilled water. The samples were filtered using Whatman No.1 pre-weighed filter paper and the filtrate was dried in an oven at $120^{\circ} \mathrm{C}$ for one hour. Following weighing, the filter papers were dried for another 10 minutes and reweighed. This was repeated until two consecutive readings were the same. Values were multiplied by ten to obtain the weight of water insoluble material in 100 $\mathrm{g}$ of honey.

\subsection{Electrical Conductivity}

$20 \mathrm{~g}$ dry matter of honey was dissolved in $100 \mathrm{~mL}$ distilled water. $40 \mathrm{~mL}$ of potassium chloride solution $(0.1 \mathrm{M})$ was transferred to a beaker. The electrical conductance (Jenway, USA) of the sample was read in $\mathrm{mS} \mathrm{cm}-1$ after the temperature had equilibrated to $20^{\circ} \mathrm{C}$.

\subsection{Hydroxymethylfurfural (HMF)}

The White method for hydroxymethylfurfural was used (International Honey Commission, 2002). Briefly, $5 \mathrm{~g}$ of honey was accurately weighed and made to volume, in a $50 \mathrm{~mL}$ volumetric flask, following the addition of $0.5 \mathrm{~mL}$ of Carrez solution I and $0.5 \mathrm{~mL}$ of Carrez solution II. The solution was filtered and $5.0 \mathrm{~mL}$ was pipetted into each of two 2 test tubes $(18 \times 150$ $\mathrm{mm}) .5 .0 \mathrm{~mL}$ of distilled water was added to one of the test tubes and mixed well (the sample solution). $5.0 \mathrm{~mL}$ of sodium bisulphite solution $(0.2$ $\%)$ was added to the second test tube and mixed well (the reference solution). The absorbance of the sample solution against the reference solution was determined at 284 and $336 \mathrm{~nm}$ in 10 mm quartz cells on a UV-VIS spectrophotometer (WPA, Lightwave II, UK) within one hour. If the absorbance at $284 \mathrm{~nm}$ exceeded a value of about 0.6 , the sample and reference solutions were diluted with distilled water and sodium bisulphite respectively. The HMF content was expressed as 


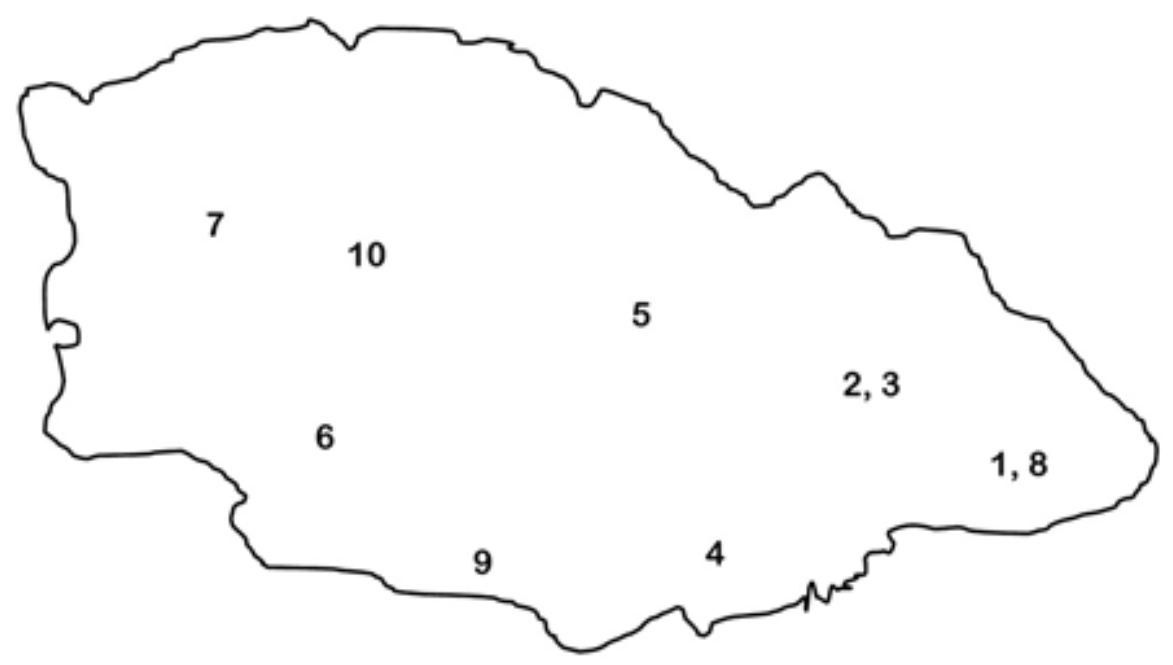

Figure 1: The distribution of honey samples collected from beekeepers on the island of Gozo. Localities for samples: 1\& 8 Qala, 2\& 3 Nadur, 4 Ghajnsielem, 5 Xaghra, 6 Kercem, 7 Gharb, 9 Sannat, 10 Ghasri

$\mathrm{mg} \mathrm{kg}^{-1}$ using the following equation:

HMF in $\mathrm{mg} \mathrm{kg}^{-1}=\frac{\left(A_{284}-A_{336}\right) \times 149.7 \times 5 \times D F}{W_{S}}$

Where $\mathrm{A}_{284}$ and $\mathrm{A}_{336}$ represent the absorbance at 284 and $336 \mathrm{~nm}$, respectively, 149.7 is a constant; DF is the dilution factor (where applicable) and $\mathrm{W}_{S}$ is the weight in grams of the honey sample.

\subsection{Polyphenolic content}

The polyphenolic content was determined spectrophotometrically by the Folin Ciocalteu reagent. About $2.5 \mathrm{~g}$ honey samples were dissolved in up to $10 \mathrm{~mL}$ of distilled water. 10 $\mu \mathrm{L}$ of the solutions were mixed with $100 \mu \mathrm{L}$ of Folin Ciocalteu reagent (Sigma, 1:10) and $80 \mu \mathrm{L}$ of $1 \mathrm{M}$ sodium carbonate (Sigma) in triplicate wells of a microtitre plate (Attard, 2013). The reaction was allowed to stand for 20 minutes at room temperature in the dark, and then read on a microtitre plate reader (BioTek ELx800, Vermont, USA) at $630 \mathrm{~nm}$. Dilutions of gallic acid, ranging from $0-960 \mu \mathrm{g} \mathrm{mL}-1$, were used for the standard curve. The polyphenolic content of honey was expressed as gallic acid equivalents (GAE) $\mathrm{mg} \mathrm{kg}^{-1}$ of honey.

Total Polyphenolic content in volume,

$$
V_{\mathrm{TPC}}\left(\mu g \cdot m l^{-1}\right)=\frac{\left(\mathrm{Abs}_{630}-\text { intercept }\right)}{\text { gradient }}
$$

Total Polyphenolic content

$$
\mathrm{mg} \cdot \mathrm{kg}^{-1}=V_{\mathrm{TPC}} \cdot \frac{V_{S}}{W_{S}} \cdot D F
$$

Where:

$\mathrm{V}_{S}=$ volume of solvent used $(10 \mathrm{~mL})$

$\mathrm{W}_{S}=$ weight of sample used $(\mathrm{g})$

$\mathrm{DF}=$ dilution factor (10)

$\operatorname{Abs}_{630}=$ Absorbance at a wavelength of $630 \mathrm{~nm}$ 


\subsection{Statistical analysis}

The $\mathrm{pH}$, total acidity, moisture content, water insoluble content, HMF content and polyphenolic content for all honey samples were investigated with multivariate analysis. The correlation matrix was calculated, giving the correlation coefficients between each pair of variables tested. To identify variability and to reduce the dimensions of the data set, principal component analysis (PCA) was performed, using the XLSTAT Version 2011.5.01 software (Addinsoft, USA).

\section{Results and Discussion}

Table 1 shows the results obtained for the honey samples examined in this study.

\section{$3.1 \mathrm{pH}$ and free acidity}

The $\mathrm{pH}$ ranged between 3.89 and 4.17 with an average value of 3.99. Although this appears to be lower than other Mediterranean types of honey (Thrasyvoulou \& Manikis, 1995; Terrab \& Heredia, 2004; Terrab, Recamales, Hernanz, \& Heredia, 2004), the $\mathrm{pH}$ range of Gozitan polyfloral honey was in accordance with that (3.42-6.10) reported by White and Doner, 1980 for floral honey and that (3.5-4.5) found by Bogdanov, Jurendic, Sieber, and Gallmann (2008). The total (titratable) acidity ranged between 26.50 and 47.50 $\mathrm{mEq} \mathrm{kg}{ }^{-1}$, falling largely within the range $(6.70$ - 47.19) reported by White and Doner (1980). Honey sample 6 showed a significantly higher total acidity when compared to the rest. The major acid is gluconic acid (White \& Doner, 1980) produced by the action of the glucose oxidase on glucose. Other acids, including some amino acids, aliphatic and aromatic acids, are important contributors to flavour in honey (National Honey Board, 2006).

No correlation was obtained between $\mathrm{pH}$ values and titratable acidity. As different honey samples have different buffering capacities, the $\mathrm{pH}$ is not necessarily an indication of the titratable acidity. The latter is a determination of the final $\mathrm{pH}$ when honey is diluted by a neutralizing medium (Molan, 1992).

\subsection{Moisture content}

The majority of the honey samples had a moisture content of twenty percent or less. However, lower water content was reported for different honey types in other studies (Thrasyvoulou \& Manikis, 1995; Tsigouri \& Passaloglou-Katrali, 2000). Samples 2 and 9, both from the same locality (Qala) exhibited a moisture content much higher than $20 \%$. A high moisture content may be indicative of prolonged exposure of the honey to humid air during extraction, or a high proportion of unsealed cells within honey which has yet to mature. A high relative humidity is one of the main problems in the Maltese Islands. However, a controlled working environment, with low relative humidity, and adequately-filled (low head space) and sealed honey containers, are key factors in limiting the absorption of water vapour from the air.

\subsection{Water insoluble content}

This parameter measures the insoluble matter in honey which includes pollen, honey-comb debris, insect fragments and other foreign bodies like unwanted particles. Hence, it indicates honey cleanliness. Wax is the major source of water-insoluble contamination (Bogdanov et al., 1999). The values ranged from 0.05 to $0.31 \%$. The limit for this parameter is $0.1 \%$ (Justice Services, 2004). Only three samples out of ten were within this limit. Due to the short period between honey harvest and testing, not enough time was allowed for water insoluble matter to settle. The filling point of the sample jars also affects the end result. If jars were filled from the surface of the bulk storage honey container, where large concentrations of minute wax particles are present, then this filling point would lead to false high results in the sample analysed.

\subsection{Electrical Conductivity}

The mean electrical conductivity of the honey samples was $0.883 \mathrm{mS} \mathrm{cm}{ }^{-1}$. This was higher than that reported in several studies, where the electrical conductivity did not exceed 0.800 $\mathrm{mS} \mathrm{cm}{ }^{-1}$ (European Commission, 2002; Huido- 
Table 1: Physicochemical characteristics for the Gozitan honey samples

\begin{tabular}{cccccccc}
\hline & $\mathrm{pH}$ & $\begin{array}{c}\text { Moisture } \\
\text { Content \% }\end{array}$ & $\begin{array}{c}\text { Acidity } \\
\left(\mathrm{mEq} \mathrm{kg}^{-1}\right)\end{array}$ & $\begin{array}{c}\mathrm{HMF} \\
\left(\mathrm{mg} \mathrm{kg}^{-1}\right)\end{array}$ & $\begin{array}{c}\text { WIC } \\
(\% \mathrm{w} / \mathrm{w})\end{array}$ & $\begin{array}{c}\text { Conductivity } \\
\mathrm{mS} \mathrm{cm}\end{array}$ & $\begin{array}{c}\text { Polyphenols } \\
\left(\mathrm{mg} \mathrm{GAE} \mathrm{kg}^{-1}\right)\end{array}$ \\
\hline 1 & $3.950 \pm 0.010$ & $20.05 \pm 0.050$ & $46.000 \pm 0.000$ & $14.171 \pm 0.649$ & 0.11 & 1.015 & $264.715 \pm 1.456$ \\
2 & $4.000 \pm 0.000$ & $22.5 \pm 0.100$ & $43.000 \pm 0.000$ & $10.626 \pm 0.456$ & 0.31 & 0.725 & $280.916 \pm 8.995$ \\
3 & $4.000 \pm 0.000$ & $19.65 \pm 0.050$ & $37.000 \pm 1.000$ & $14.371 \pm 1.507$ & 0.12 & 0.862 & $261.326 \pm 2.563$ \\
4 & $3.950 \pm 0.010$ & $19.05 \pm 0.050$ & $33.000 \pm 1.000$ & $7.385 \pm 0.956$ & 0.14 & 0.777 & $236.555 \pm 1.236$ \\
5 & $3.960 \pm 0.000$ & $20.3 \pm 0.000$ & $35.500 \pm 0.500$ & $8.833 \pm 0.915$ & 0.06 & 1.104 & $258.423 \pm 1.741$ \\
6 & $3.890 \pm 0.010$ & $20.3 \pm 0.100$ & $47.500 \pm 1.500$ & $7.585 \pm 0.908$ & 0.06 & 0.732 & $238.893 \pm 0.000$ \\
7 & $4.170 \pm 0.010$ & $19.75 \pm 0.050$ & $27.500 \pm 0.500$ & $15.819 \pm 1.510$ & 0.11 & 0.851 & $269.093 \pm 0.000$ \\
8 & $4.120 \pm 0.000$ & $19.6 \pm 0.000$ & $34.500 \pm 0.500$ & $14.920 \pm 1.151$ & 0.05 & 0.964 & $294.209 \pm 2.274$ \\
9 & $3.900 \pm 0.000$ & $21.3 \pm 0.100$ & $26.500 \pm 0.500$ & $2.894 \pm 0.506$ & 0.13 & 1.009 & $240.306 \pm 1.629$ \\
10 & $3.960 \pm 0.000$ & $19.75 \pm 0.050$ & $30.500 \pm 0.500$ & $20.858 \pm 0.932$ & 0.12 & 0.794 & $262.291 \pm 1.940$ \\
\hline
\end{tabular}

bro and Simal, 1984; Accorti, Persano-Oddo, Piazza, and Sabatini, 1986; Serra-Bonvehi, 1989; Martinez-Gomez, Guerra-Hernandez, MontillaGomez, and Molins-Marin, 1993; Owayss, 2005). Due to the small size of the island, atmospheric and soil salinity is relatively high $(\mathrm{PAP} / \mathrm{RAC}$, 2005; Vella, 2001), hence leading to higher conductivity values in the final product. This is reflected in the accumulation of proline due to increased stress caused by salinity (Jouve, Hoffmann, \& Hausman, 2004).

\subsection{Hydroxymethylfurfural (HMF)}

HMF content ranged significantly for the honey samples studied. Half the samples exhibited an HMF value of $10 \mathrm{mg} \mathrm{kg}^{-1}$ or lower. High HMF values are expected when the honey is heated prior to bottling, or when it deteriorates with prolonged storage. In this case, the high HMF values were mainly due to heating. This is because the local population prefer liquefied honey, which involves heating. One other possible reason is exposure to the hot climate. Mean HMF content for Greek honey samples did not exceed $5.6 \mathrm{mg} \mathrm{kg}^{-1}$ according to the study conducted by Thrasyvoulou and Manikis (1995). It is usually agreed that fresh honey contains minimal amounts of HMF (White, 1979), that rarely exceeds the $10 \mathrm{mg} \mathrm{kg}^{-1}$ value (Rodgers, 1979). However, for the local samples, as in other subtropical countries, the HMF values are still within the $80 \mathrm{mg} \mathrm{kg}^{-1}$ maximum content (Codex Alimentarius Commission, 1989). HMF quantification is definitely an important parameter linked to the shelf-life of the honey.

\subsection{Polyphenolic content of honey}

The polyphenolic content of Gozitan honey ranged between 236.555 - $294.209 \mathrm{mg} \mathrm{GAE} \mathrm{kg}^{-1}$. These honey types exhibited higher polyphenolic contents than coconut honey, which was reported as $15.6 \mathrm{mg} \mathrm{kg}^{-1}$ by Aljadi and Kamaruddin (2004) and acacia and fir honey samples which were respectively reported as having values of 44.8 and $5 \mathrm{mg} \mathrm{kg}^{-1}$ (Bertoncelj, Dobersek, M. \& Golob, 2007). On the other hand, Beretta, Granata, Ferrero, Orioli, and Facino (2005), reported polyphenolic contents of $789.6 \mathrm{mg} \mathrm{kg}^{-1}$ for strawberry tree honey and $482.2 \mathrm{mg} \mathrm{kg}^{-1}$ for buckwheat honey, superior to the honey samples under study.

\subsection{Statistical Analysis}

It was observed that from the screen plot (data not shown) that the first five principal components account for $96.88 \%$ of the total variance. This indicates that there is little numerical noise and/or experimental error. However, the first two principal components contributed significantly to the total variance. The loading plot provides the direction of each original variable, and the scores' plot, indicates the position of each honey sample. The first factor is loaded heavily on $\mathrm{pH}$, HMF content and polyphenolic content, representing variables that are all chemical in nature. The second factor is heavily loaded 

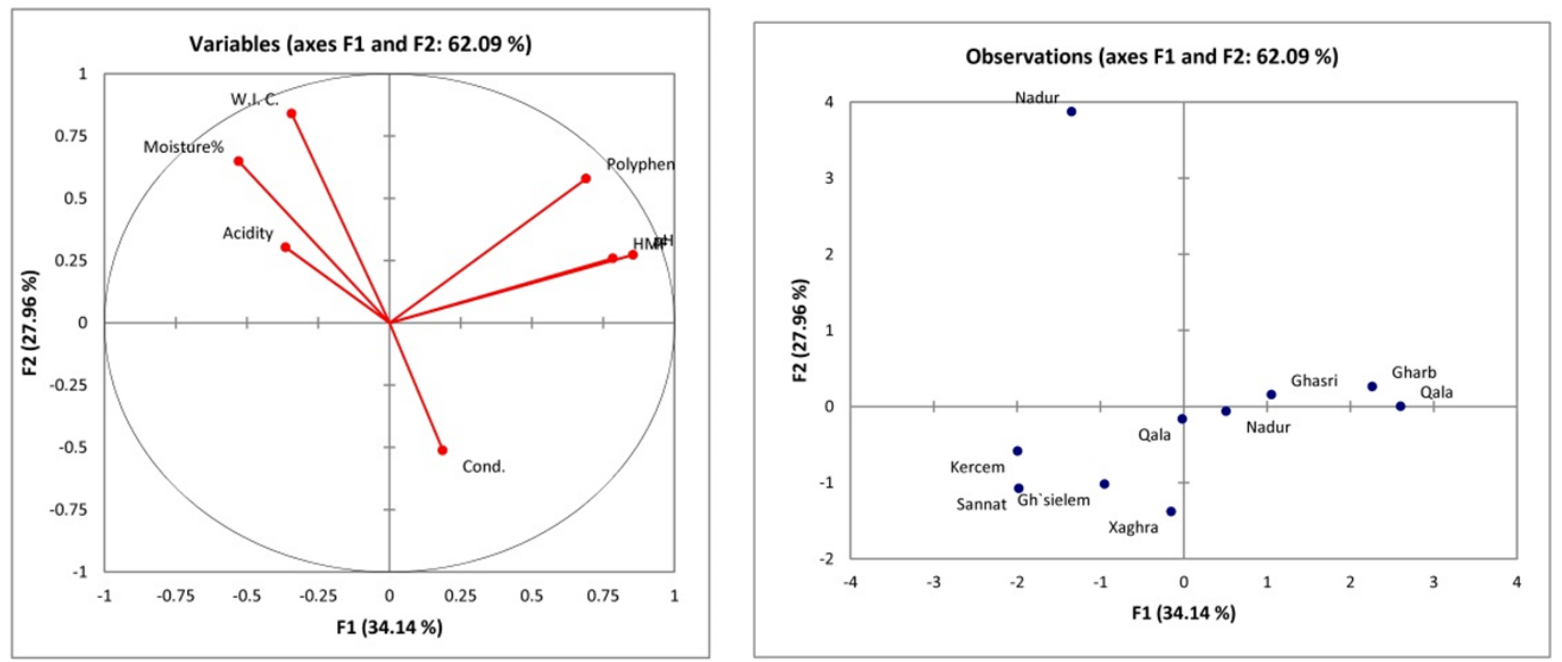

Figure 2: Loading plot (A) of physicochemical parameters and scores' plot (B) of various honey samples from different zones within the island of Gozo.

on water insoluble content and moisture content. The sugar content derived from the moisture content showed an inverse correlation with $\mathrm{HMF}$ content, indicating that the HMF build up depends on the dissipation of sugars through the Maillard reaction. Acidity showed an inverse relationship with conductivity because there are other contributing ions as well as hydrogen ions. Even water insoluble content exhibited an inverse relationship with conductivity (Fig. 2A). This is because conductivity is a measure of the content of soluble salts.

The scores' plot reported in Fig. 2B shows the physicochemical parameters of honey in the space of the two new variables F1 and F2. Moving along $\mathrm{F} 1$ from left to right in the graph, we find different patterns of grouping with honey samples (4, 6 and 9) having low pH, HMF content and polyphenolic content from the southern zone of Gozo while honey samples $(3,7,8$ and 10) have higher values for these parameters from the northern zone of Gozo. Honey sample 5 from the central part of the island exhibited intermediate values for the parameters mentioned. Honey samples (2, 3, 7 and 10) from the northern zone of Gozo exhibited distinctively lower conductivity values, but higher water insoluble content than those from the southern zone.

\section{Conclusions}

The aim of the work was to identify differences in physicochemical parameters of honey sources originating from a small island. Though the honey samples showed different physicochemical characteristics, chemometric (polyphenolic content) and environmental indicators (electrical conductivity, acidity) clearly suggest that honey samples originate from different zones even though the island of Gozo is very small. It is implied that floral and soil substrates play an important role in the characterisation of honey. The findings from this study can provide the melissopalynologist with an idea of floral variations within different zones of a studied region.

\section{References}

Accorti, M., Persano-Oddo, L., Piazza, M., \& Sabatini, A. (1986). Schede di caratterizzazione delle principali qualita di miele italiano. Apicoltura, 2(36), 1325. 
Aljadi, A., \& Kamaruddin, M. (2004). Evaluation of the phenolic contents and antioxidant capacities of two Malaysian floral honeys. Food Chemistry, 85(4), 513-518. doi:10.1016/S0308-8146(02)00596-4

Attard, E. (2013). A rapid microtitre plate FolinCiocalteu method for the assessment of polyphenols. Central European Journal of Biology, 8(1), 48-53. doi:10.2478/s11535012-0107-3

Beretta, G, Granata, P, Ferrero, M, Orioli, M, \& Facino, R. (2005). Standardization of antioxidant properties of honey by a combination of spectrophotometric/fluorimetric assays and chemometrics. Analytica Chimica Acta, 533(2), 185-191. doi:10.1016/j.aca. 2004.11.010

Bertoncelj, J., Dobersek, U., M., J., \& Golob, T. (2007). Evaluation of the phenolic content, antioxidant activity and colour of slovenian honey. Food Chemistry, 105(2), 822-828. doi:10.1016/j.2007.01.060

Bogdanov, S, Lullmann, C, Martin, P, von der Ohe, W, Russmann, H, Vorwohl, G, ... Commission, I. H. (1999). Honey quality and international regulatory standards: review by the International Honey Commission. Bee World, 80(2), 61-69.

Bogdanov, S., Jurendic, T., Sieber, R., \& Gallmann, P. (2008). Honey for Nutrition and Health: A Review. Journal of the American College of Nutrition, 27(6), 677-689.

Codex Alimentarius Commission. (1989). Codex standard for honey (worldwide standard). FAO-WHO, CAC 3, Ed 1 Supp 2, Rome.

Crane, E. (1983). The archeology of beekeeping. UK: Gerarld Duckworth \& Co. Ltd.

European Commission. (2002). Council Directive 2001/110/EC. Official Journal, L 010, 4752.

Huidobro, J., \& Simal, J. (1984). Determinacion del color y la turbidez en las mieles. anales de bromatologica. Apicultural Abstracts, 648/1988, 36(2), 225-245.

International Honey Commission. (2002). Harmonised Methods of the International Honey Commission. Bern Switzerland: Swiss Bee Research Centre, pp. 62.

Jouve, L, Hoffmann, L, \& Hausman, J. (2004). Polyamine, carbohydrate, and proline con- tent changes during salt stress exposure of aspen (Populus tremula L.): Involvement of oxidation and osmoregulation metabolism. Plant Biology, 6(1), 74-80. doi:10.1055/s2003-44687

Justice Services. (2004). Legal Notice 213 - Subsidiary Legislation 449.38, Government of Malta, Honey Regulations, S.L.449.38, 1-5.

Lanfranco, G. (2001). Medicina popolari ta" limghoddi fil-gzejjer maltin. valletta: klabb kotba maltin, 4, 69, 110-1, 117, 126, 140, 218.

Martinez-Gomez, M., Guerra-Hernandez, E., Montilla-Gomez, J., \& Molins-Marin, J. (1993). Physicochemical analysis of spanish commercial eucalyptus honeys. J. Apic. Res. 32(3/4), 121-126.

Molan, P. (1992). He antibacterial activity of honey: 1 . the nature of the antibacterial activity. Bee World, 73(1), 5-28.

National Honey Board. (2006). pH \& Acids in Honey Fact Sheet. Food Technology Program. May 28, 2007. Retrieved from http: //www.honey.com/images/downloads/phacidsinhoney.pdf

Owayss, A. A. (2005). Physicochemical analysis for standardizing quality criteria of libyan eucalyptus (eucalyptus sp.) honey. Egypt J. of Appl. Sci. 20(6A), 247-255.

PAP/RAC. (2005). Priority Actions Programme Regional Activity Centre. Coastal Area Management in the Maltese Islands, Priority Actions Programme Regional Activity Centre, Split.

Rodgers, P. (1979). Honey quality control. In E. Crane, eds: Honey, A Comprehensive Survey, Heinemann, London, 314-325.

Serra-Bonvehi, J. (1989). Caracteristicas fisicoquimicas y composición de la mile de eucalipto (eucalyptus sp.) producidación en españa. Anales de Bromatologia, 41(1), 4156.

Sheppard, W., Arias, M., Grech, A, \& Meixner, M. (1997). Apis mellifera ruttneri, a new honey bee subspecies from Malta. Apidologie, 28(5), 287-293. doi:10.1051/apido: 19970505

Terrab, A, \& Heredia, F. (2004). Characterisation of avocado (Pleirsea americana Mill) honeys by their physicochemical charac- 
The quality of Gozitan Honey $\mid 187$

teristics. Journal of The Science of Food and Agriculture, 84 (13), 1801-1805. doi:10. $1002 /$ jsfa. 1888

Terrab, A, Recamales, A., Hernanz, D, \& Heredia, F. (2004). Characterisation of Spanish thyme honeys by their physicochemical characteristics and mineral contents. Food Chemistry, 88(4), 537-542. doi:10.1016/j. foodchem.2004.01.068

Thrasyvoulou, A, \& Manikis, J. (1995). Some physicochemical and microscopic characteristics of Greek unifloral honeys. Apidologie, 26 (6), 441-452. doi:10.1051/apido: 19950601

Tsigouri, A, \& Passaloglou-Katrali, M. (2000). A scientific note on the characteristics of thyme honey from the Greek island of Kithira. Apidologie, 31 (3), 457-458. doi:10. 1051/apido:2000137

Vella, S. (2001). Soil Information in the Maltese Islands. In P. Zdruli, P. Steduto, C. Lacirignola, L. Montanarella, Bari (Eds.): Soil Resources of Southern and Eastern Mediterranean Countries. CIHEAM, [ISBN:285352-227-X]. Options Méditerranéennes, B, 34, 171-198.

White, J. (1979). Composition of honey. In $E$. Crane (Eds.): Honey, A Comprehensive Survey, Heinemann, London, 157-206.

White, J., \& Doner, L. (1980). Honey composition and properties. Beekeeping in the United States Agriculture Handbook Number, 335, 82-91. 